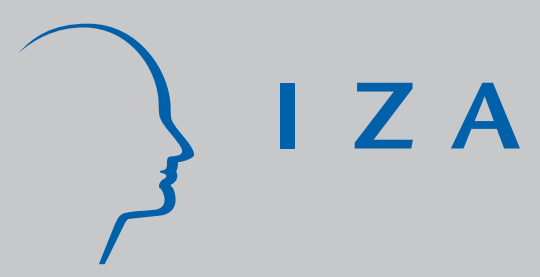

IZA DP No. 649

From Parent to Child: Early Labor Market Experiences of Second-Generation Immigrants in the Netherlands

J an C. van Ours

J ustus Veenman

November 2002 


\title{
From Parent to Child: Early Labor Market Experiences of Second-Generation Immigrants in the Netherlands
}

\author{
Jan C. van Ours \\ CentER, Tilburg University, OSA, \\ CEPR and IZA Bonn \\ Justus Veenman \\ ISEO, Erasmus University Rotterdam \\ and Tinbergen Institute
}

\section{Discussion Paper No. 649 \\ November 2002}

\author{
IZA \\ P.O. Box 7240 \\ D-53072 Bonn \\ Germany \\ Tel.: +49-228-3894-0 \\ Fax: +49-228-3894-210 \\ Email: iza@iza.org
}

This Discussion Paper is issued within the framework of IZA's research area Mobility and Flexibility of Labor. Any opinions expressed here are those of the author(s) and not those of the institute. Research disseminated by IZA may include views on policy, but the institute itself takes no institutional policy positions.

The Institute for the Study of Labor (IZA) in Bonn is a local and virtual international research center and a place of communication between science, politics and business. IZA is an independent, nonprofit limited liability company (Gesellschaft mit beschränkter Haftung) supported by the Deutsche Post AG. The center is associated with the University of Bonn and offers a stimulating research environment through its research networks, research support, and visitors and doctoral programs. IZA engages in (i) original and internationally competitive research in all fields of labor economics, (ii) development of policy concepts, and (iii) dissemination of research results and concepts to the interested public. The current research program deals with (1) mobility and flexibility of labor, (2) internationalization of labor markets, (3) welfare state and labor market, (4) labor markets in transition countries, (5) the future of labor, (6) evaluation of labor market policies and projects and (7) general labor economics.

IZA Discussion Papers often represent preliminary work and are circulated to encourage discussion. Citation of such a paper should account for its provisional character. A revised version may be available on the IZA website (www.iza.org) or directly from the author. 
IZA Discussion Paper No. 649

November 2002

\section{ABSTRACT}

\section{From Parent to Child: Early Labor Market Experiences of Second-Generation Immigrants in the Netherlands*}

This paper is on the early labor market experiences of second-generation immigrants in the Netherlands. We find that only for employment rates there are some differences across ethnic groups. Conditional on having a job there is hardly any difference in wages and other job characteristics between second-generation immigrants and native Dutch of the same age group.

JEL Classification: J15, J61

Keywords: second-generation immigrants, ethnic minorities, labor market

Corresponding author:

Jan C. van Ours

CentER for Economic Research

P.O. Box 90153

5000 LE Tilburg

The Netherlands

Tel.: +31 134662316

Fax: +31134663042

Email: vanours@uvt.nl

\footnotetext{
* The authors thank participants of the 2002 EALE annual conference (Paris) for their comments on a previous version of the paper. They also thank the Institute for Labor Studies (OSA) for financial support.
} 


\section{Introduction}

In the course of the second half of the twentieth century a lot of European countries changed from emigration countries to immigration countries. In the past two decades the majority of the new immigrants came to Europe because of family reunification, but in earlier decades the driving force of the immigration was the demand for low-skilled workers in the manufacturing sector. Apart from labor market induced immigration many European countries had immigrant flows from former colonies. The immigrant population has a different structure than the population in the receiving countries. On average, the share of low-skilled workers among immigrants is substantially higher than among the native population. This is one of the reasons why unemployment rates among immigrant groups in Europe are often above average. Although in the course of time immigrants may integrate in the European labor markets unemployment rates among immigrant groups are still much higher than among native Europeans (Coppel et al., 2001). Now, at the beginning of the 21ste century in many European countries immigrant children, i.e. second-generation immigrants, are reaching the age at which they finish their education and enter the labor market. An important policy question is whether the second-generation immigrants have closed the socioeconomic gap with native inhabitants. Therefore, it is interesting to compare early labor market experiences of second-generation immigrants with the position of native Europeans of the same age group.

Well-known US studies on the position of immigrants are Borjas (1992) and Borjas (1995) that focus on ethnic capital, spillovers from ethnic neighborhoods and the persistence of skills and earnings across generations. Card et al. (1998) find important links between the economic status of immigrant fathers and the economic status and marriage patterns of their native sons and daughters. Much of this linkage works through education: children of better-educated immigrants have higher education, earn higher wages, and are more likely to marry outside of their father's immigrant group. Children of immigrants tend to have noticeably higher education and wages than the children of natives, controlling for parental 
background.

The educational position of second-generation immigrants has also been the topic of research in a variety of European studies, particularly with German data. Gang (1997) analyzes German data indicating that parental schooling may be a proxy for a host of unobservable determinants, such as parental preferences for education, children's ability, and assistance given by parents in school work. Furthermore, parental schooling variables are proxies for the efficiency with which parents can invest in children's education (a price effect) and the economic resources parents have available to invest in their children (an income effect). He concludes that there are large differences in the human capital formation across ethnic groups and gender. While there is some assimilation across generations, it is far from complete. Gang and Zimmermann (2000) analyze a sample from a survey of second-generation immigrants in Germany. They define second-generation immigrants as children of first generation immigrants born in Germany or arriving in Germany before the age of 16 . They investigate to what extent the parental human capital i.e. the educational attainment of parents, influences the educational attainment of children. They conclude that for foreign-born parental schooling plays no role in the educational choice of their children. Furthermore, they conclude that there is convergence in the acquisition of education taking place. However, ethnicity still has a strong effect on educational attainment, which indicates that social and cultural differences persist. According to Riphahn (2001a) who also studies the German situation, effects of parental schooling are very strong. Children of parents with no or a low educational degree have a significantly lower probability to attend advanced school. Furthermore, longer presence in the destination country appears to be positively correlated with child enrollment in advanced education. Riphahn (2001b) concludes that educational success appears to be correlated particularly with the ability to speak German, while the writing ability effect is statistically insignificant. Parent education is significant only for natives. This corroborates the finding of Gang and Zimmermann (2000), who conclude that the first generation's human capital is completely depreciated upon migration. 
Frick and Wagner (2001) make a distinction between native born Germans, German immigrants and foreigners. They also distinguish between children in households of 'single' ethnicity and children in households of 'mixed' ethnicity. They conclude that educational levels between different generations of the same household are highly correlated, while there is no significant effect for the simple immigration dummy. The latter means that the immigrants status per se does not account for the descriptive differences in enrollment, but rather other socioeconomic effects.

There are also a couple of Scandinavian studies. Österberg (2000) defines young immigrants as those born abroad but arriving to Sweden before the age of 16. She finds that observed low educational levels among Swedish immigrant's children are mostly due to the low socioeconomic position of parents. Furthermore, she finds that immigrant children are more often unemployed, but once employed there is no difference between immigrants and native Swedes. Månsson and Ekberg (2001) define second-generation immigrants as persons born in Sweden with both immigrated parents born outside Sweden. They find that second-generation immigrants have a smaller probability to be employed than otherwise similar native Swedes. They do not find that wages of secondgeneration immigrants are different from Swedish wages.

Skyt Nielsen et al. (2001) investigate the Danish situation concerning qualifying education, waiting time from leaving school to the first ordinary job and the duration of the first job or employment spell. The focus is on intergenerational effects working through parental capital, ethnic capital, and neighborhood effects. All estimates are done separately for second-generation immigrants and ethnic Danes. They find that the concentration of immigrants in the current neighborhood has a positive effect on immigrants earnings. The experience profiles are flatter for immigrants than for ethnic Danes. The effect of one extra year of education is much lower for second-generation immigrants, especially males, than for ethnic Danes. The strongest effects of intergenerational transmissions happen in the educational attainment of the second-generation immigrants.

Finally there are a number of Dutch studies. De Graaff et al. (2000) find 
that ethnic capital and geographical clustering of ethnic minorities at the neighborhood level does not seem to have a large impact on educational attainment. Van Ours and Veenman (2003a) give a description of the disadvantageous position of Turkish, Moroccan, Surinamese and Antillean immigrants. Van Ours and Veenman (2003b) conclude that the difference in educational level of the parents is driving the differences in educational attainment between second-generation immigrants and native Dutch. If these differences are taken into account, the differences between second-generation immigrants and native Dutch vanish to a large extent.

The current study is on the early labor market experiences of second-generation immigrants in the Netherlands. The focus is on four important ethnic minority groups: Turks, Moroccans, Surinamese and Antilleans. The set-up of the paper is as follows. In section 2 we give a description of the population of immigrants in the Netherlands. Section 3 considers their labor market position by investigating to what extent schoolleavers have jobs. Section 4 deals with job characteristics like type of contract, working hours, job level and wages. Section 5 concludes.

\section{Immigrants in the Netherlands}

Since the beginning of the 1960s the Netherlands has had a net immigration, i.e. immigration was larger than emigration. The immigration of the past decades originates from two rather different processes. The de-colonization caused peaks in immigration in specific years while the hiring of immigrant workers - because of cyclical labor shortages - turned out to have a structural character. Current labor market problems are to some extent related to the shift in immigration from a business cycle phenomenon to a structural process. In the 1960's immigrant workers were hired because the Dutch labor market was booming. The immigrant workers got jobs in industries with low paid labor. Since these industries were particularly hit by the economic recession of the 1980's, many immigrant workers lost their jobs to become long term unemployed. 
Now, at the beginning of the new millennium about 2.7 million people live in the Netherlands, who by their own birthplace or that of at least one of their parents are considered to be immigrants. Together they comprise about $17 \%$ of the total population. As counted in 1999, the largest groups of immigrants are Turks $(300,000)$, Surinamese $(297,000)$, Moroccan $(250,000)$, Antilleans $(99,000)$ and people from (former) Yugoslavia (63,000). Immigrants from the southern European countries comprise about 90,000 people, who have different nationalities. Even more diversity of nationality is found among the political refugees, who comprise about 180,000 people. As far as immigrants are concerned we focus on Turks, Moroccans, Surinamese and Antilleans.

Until now, the second generation has been loosely defined. To adequately answer our central research question, we have to be more precise. For our analyses in this paper, we will define second-generation immigrants as (a) those who were born in the Netherlands from at least one parent who came there as an immigrant and (b) those who arrived as an immigrant in the Netherlands at a very young age. From previous research (Martens and Veenman (1996)) we know that a strong determinant of the educational careers of immigrant is the moment they start to participate in the educational system of the immigrant country. It was calculated that in the Netherlands the decisive age limit for significant drawbacks from migration, is 6 years. We therefore include those who arrived in the Netherlands at an age under 6 years in the second-generation immigrants.

The data we use in our analysis are from 1998 and are described more in detail in the appendix. The share of second-generation immigrants in the total group of immigrants declines rapidly with age. At the age of 10 about $95 \%$ are second-generation, at age 20 this is $60 \%$ and at age 30 only $10 \%$ of the immigrants belong to the second generation. Therefore, we focus on secondgeneration immigrants in the age category $15-29$ years. As shown in the appendix within this age category there is a big difference in average age across the different groups in the sample. On average native Dutch are a couple of years older than the ethnic minority groups. 


\section{Leaving school, finding jobs}

\subsection{At school and/or at work}

Table 1 shows the schooling and labor market position of the individuals in our sample distinguished by gender and ethnic group. Of native Dutch males $39 \%$ is at school, while of native Dutch females $46 \%$ is at school. Of all the other groups more than $50 \%$ is still at school. Of course this has to do with the differences in average age across the groups. As is also clear from Table 1 many youngsters at school have a job. In these jobs the average number of weekly working hours is between 5 and 8 . Across the groups the differences in working hours of schoolattenders are not big. Even for schoolleavers the differences in working hours are gender related. For working females the average number of weekly working hours ranges from 24 to 29 . For working males the range is from 28 to 33 . So within the gender categories the differences across group are not very large. Having a job while being at school is more popular among native Dutch then it is among Antilleans and Surinamese and much more popular then it is among Turks and Moroccans. Roughly speaking about half of the native Dutch youngsters has a job while at school, while this is the case for only one in three Surinamese and Antillean youngsters and only one in four Turkish and Moroccan youngsters. With respect to employment rates (employment as a percentage of the population) for schoolleavers there are also obvious differences between genders and across ethnic groups. The employment rate among males is always higher than the employment rate among females, except for Surinamese youngsters where the employment rates are about the same for males and females. Employment rates of schoolleavers are highest for native Dutch and Antilleans, lower for Surinamese and lowest for Turkish and Moroccan youngsters. Unemployment rates (unemployment as a percentage of the labor force) are highest among Moroccans and lowest among native Dutch and Antilleans.

We start our empirical analysis with the probability that an individual has 
a job while he or she is still at school. For this we use a simple probit model

$$
\begin{aligned}
& \operatorname{Pr}\left(e_{i}=1\right)=\Phi\left(\gamma^{\prime} z_{i}\right) \\
& \operatorname{Pr}\left(e_{i}=0\right)=\Phi\left(-\gamma^{\prime} z_{i}\right)
\end{aligned}
$$

where $y$ indicates whether $(e=1)$ or not $(e=0)$ individual $i$ has a job, $\Phi$ is the symbol for the normal distribution, $z$ is a vector of personal characteristics including age, parental occupation, neighborhood characteristics and ethnicity (see the appendix for definitions) and $\gamma$ is a vector of parameters of interest. The estimation results are shown in Table 2. It appears that having a job while being at school is an age related phenomenon. With an increase of the age the likelihood that an individual combines school with work increases. The level of education is not a relevant determinant, nor are neighborhood characteristics relevant. Whether or not the occupational level of the parents is known, which is in itself an indication about whether or not the parents are unemployed, has a strong effect on the probability to combine school with work. Apparently it is less likely for a child with unemployed parents to combine school with work. Conditional on the other characteristics Turkish and Moroccan girls are less likely to combine school with work than other groups. For males we do not find significant differences across ethnic groups.

\subsection{Leaving school}

To find a relationship between individual characteristics and the probability that an individual has left school we again estimated a probit model. Now we have $\operatorname{Pr}\left(s_{i}=1\right)=\Phi\left(\beta^{\prime} x_{i}\right)$ and $\operatorname{Pr}\left(s_{i}=0\right)=\Phi\left(-\beta^{\prime} x_{i}\right)$, where $s$ indicates whether $(s=1)$ or not $(s=0)$ individual $i$ has left school and $x$ is a vector of personal characteristics. Table 3 shows the estimation results. As was to be expected this probability increases with age. Apart from age there are hardly any personal characteristics that affect the probability to be a schoolleaver. Both males and females are more likely to be a schoolleaver if the father has primary education. Furthermore, Turkish boys are more likely than boys from other ethnic groups to be schoolleaver, conditional on his age and other characteristics. 
Table 4 gives an overview of the educational level attained by schoolleavers. There are clear differences between genders and across ethnic groups. For all groups except for Turks the educational level of females is higher than the educational level of males. The educational attainment of Antilleans is about the same as the educational attainment of native Dutch. The educational attainment of Turks and Moroccans is substantially lower, while the educational attainment of Surinamese youngsters is in between. In Van Ours and Veenman (2003b) we find that conditional on the education of their parents most immigrant groups have an educational attainment that is similar to native Dutch. To the extent that there are differences between these groups at the aggregate level, like in Table 4, these are related to differences in education of the parents: the lower the education of the parents the lower the school attendance of the children.

\subsection{Finding a job}

Going to school is obligatory in the Netherlands until age 15. Then, at age 15 and 16 individuals can go into the labor market or stay at home but they are still obliged to attend part-time education. Like the situation concerning school-leaving the labor market position of individuals is also age dependent.

We focus on the probability to have a job conditional on being out of school. There are three types of observations $\left\{s_{i}=0\right\},\left\{s_{i}=1, e_{i}=0\right\},\left\{s_{i}=1, e_{i}=1\right\}$. We use a bivariate Probit model in which we account for possible selectivity:

$$
\begin{aligned}
& \operatorname{Pr}\left(s_{i}=0\right)=\Phi\left(-\beta^{\prime} x_{i}\right) \\
& \operatorname{Pr}\left(s_{i}=1, e_{i}=0\right)=\Phi_{2}\left(\beta^{\prime} x_{i},-\gamma^{\prime} z_{i},-\rho\right) \\
& \operatorname{Pr}\left(s_{i}=1, e_{i}=1\right)=\Phi_{2}\left(\beta^{\prime} x_{i}, \gamma^{\prime} z_{i}, \rho\right)
\end{aligned}
$$

where $\Phi_{2}$ is the symbol for a bivariate probit, $x$ and $z$ are personal characteristics $\beta$ and $\gamma$ are vectors of parameters and $\rho$ indicates the correlation between the two processes of schoolleaving and job-finding. The parameter estimates are shown in Table 5. Since the parameters of the process of schoolleaving are very similar to the ones reported in Table 3 we only report the parameters of the 
job-finding process. For females we find that education has a positive effect on the probability to have a job. Females with intermediate or higher education have a significant higher probability to have a job than females with a lower education. Neighborhood characteristics and potential experience do not affect the probability to have a job. Furthermore, it appears that conditional on their education, working experience and neighborhood female Turks and Moroccans are less likely to have job. In the second column of Table 5 we show parameter estimates after including a dummy variable for missing information about parental occupation, which we interpret as an indication for parental unemployment. Comparing the coefficients for the ethnic groups in the two columns it appears that the inclusion of parental unemployment reduces the negative effects of ethnicity. Apparently parental unemployment, which is disproportionately high among ethnic minorities is also at least partial responsible for non-employment of immigrant children. In fact, if we remove the individuals with an unemployed parent from the sample we only find a significant ethnicity effect for Turkish females. By and large we find similar results for males. Here too there is an effect of parental unemployment on the employment position of children. There is no effect of education on the probability to have a job. Conditional on education, neighborhood and work experience Turks, Moroccans and Surinamese have a smaller probability to have a job than males from the other ethnic groups. ${ }^{1}$

An important question is why some of the ethnic minority youngsters have a smaller probability than native youngsters to have a job. Firstly, this has to do with voluntary withdrawal from the labour market, a phenomenon which is widespread among young Turkish and Moroccan women from the more traditional Islamic families. Opposite to this self-exclusion among women is the social exclusion of young men from these groups. While in general there is strong family pressure to find a job and start a family of procreation at a relatively

\footnotetext{
${ }^{1}$ In the appendix we show additional estimation results concerning the probability to be in the labor force and the probability to be unemployed. By and large these results are in line with the parameter estimates in Table 5.
} 
young age, it is possible that Turkish and Moroccan men experience discrimination in the Dutch labour market. Such discrimination could result both from a negative prejudice against Muslim in general, more specific against Turks and Moroccans, and from negative stereotyping of their work performance (Veenman, 1995; Kruisbergen and Veld, 2002). Another explanation could be that Turkish, Moroccan and also Surinamese men have higher reservation wages and are therefore less likely to accept a job. This is related to the observation that both Turkish and Moroccan men and women have a high rate of black-paid jobs in immigrant enterprises, which covers up their labor market participation, also in survey data. It was found that Surinamese young men have a lower participation rate because of the 'hustle'-culture, which implies that they are active in all kind of small trades, inclusive illegitimate activities (Veenman, 1996).

\section{Job characteristics}

Now that we established differences between ethnic groups in terms of their employment rates we investigate whether there are differences between ethnic groups in terms of job characteristics. Table 6 gives an overview of the job characteristics we investigate. As shown for females the percentage of workers with a steady job ranges from 73 to 88 percent, with Surinamese and Turkish females having the least steady jobs and Moroccan and native Dutch females have the most steady jobs. The differences between the males are not very large ranging from $78 \%$ steady jobs for Surinamese to $87 \%$ of steady jobs for Moroccans and native Dutch. As was already indicated when discussing Table 1 in terms of working hours the main differences are between males and females and not across ethnic groups. Of the females about $65-70 \%$ has a full-time job, while of the males $85-95 \%$ has a full-time job. Furthermore, Table 6 shows the job level, calculated as an average over the job level classification that ranges from 0 to 3. The highest job levels are attained by Antilleans and native Dutch. Finally, Table 6 presents average net hourly wages, which turn out to be highest for natives and Antillean females and lowest for Turkish females. 


\subsection{Type of contract}

\subsubsection{Steady jobs, full-time jobs}

Estimation results with respect to steady jobs are shown in Table 7 . The parameters are based on a bivariate probit model with selection on whether or not an individual has a job. As shown for females the probability to have a steady job increases with potential work experience, which makes sense because a lot of youngsters start on a temporary job and "grow into" a steady job as they gather more work experience. Educational level and neighborhood characteristics do not affect the probability to work on a steady job. Conditional on the work experience Turkish and Surinamese females are less likely to work on a steady job. Also for males we find a positive relationship between potential work experience and the probability to work on a steady job. For males education matters. Workers with intermediate or higher education are more likely to work on a steady job. Neighborhood characteristics turn out to be irrelevant. Conditional on education and potential work experience for males there are no differences between ethnic groups.

Table 7 also shows the parameter estimates for the probability to work on a full-time job. Neither for males nor for females we find a parameter that is different from zero at conventional level of significance. Apparently, whether or not an individual has a part-time job or a full-time job is not related to his or her observed characteristics.

\subsubsection{Job level}

Estimation results with respect to the job level attained are shown in Table 9. The parameter estimates are based on a bivariate ordered probit model with selection on whether or not an individual has a job. As shown for females the probability to have a high job level increases with the educational level. The distinction is between females with higher education and others, where the females with a higher education have a substantially higher probability to work on a higher job level. Furthermore, the expected job level increases 
with potential work experience, which makes sense because to "grow into" a higher job level requires work experience. The neighborhood characteristics are irrelevant. Conditional on the educational level and potential work experience for females there is no significant difference across the ethnic groups.

For males we also find that higher educated workers have a higher expected job level. Potential work experience and neighborhood characteristics do not matter. Conditional on education Turkish and Surinamese males have a lower expected job level.

\subsection{Wages}

Finally, we investigate to what extent there are differences across ethnic groups in net wages. To analyze potential determinants of $(\log )$ net wages we did earnings regressions taking possible selectivity into account, with a Mill's ratio based on the probit estimates for having a job. Table 9 shows the estimation results. It appears that only for males education has a positive effect on wages. The average difference in net wages between males with a higher educational level and other males equals $32 \%$. Neighborhood characteristics and ethnicity are irrelevant. Furthermore, steady jobs pay more than temporary jobs. The difference amount to $18 \%$ for males and $15 \%$ for females. Finally, potential work experience has a positive effect of about $3.2 \%$ per year for females and $2.4 \%$ for males.

\section{Conclusion}

This study is on the educational and labor market position of young secondgeneration immigrants. The focus is on the four main groups of ethnic minorities in the Netherlands: Turks, Moroccans, Surinamese and Antilleans. From a direct comparison it appears that especially Turkish and Moroccan immigrant children are not performing as well as native Dutch youngsters. Young Surinamese and Antilleans are also doing worse than their Dutch counterparts, but for them the differences are smaller. When leaving school the average educa- 
tional level of these ethnic groups is lower, the participation in the labor market is lower and if they participate they are less likely to have a job.

In our study we focus on the influence of personal characteristics, family background and neighborhood conditions. Our main conclusions are the following. The neighborhood, in terms of ethnic composition, does not seem to have a large effect on the labor market position of second-generation immigrants. After correcting for the influence of personal characteristics and family background we find that ethnicity is not very important. Employed workers have a job with similar characteristics irrespective of their ethnicity. Wagea, job levela, probabilities to have a steady job and probabilities to have a full-time job are almost the same for second-generation immigrants and native Dutch youngsters. The main exception where there is a difference across ethnic groups concerns the employment rate. After correcting for the influence of other determinants Turkish, Moroccan and Surinamese second-generation immigrants have a smaller likelihood of having a job than other groups do. A special feature of the analysis performed here is that the effect on the probability of having a job is strongly influenced by whether or not parents have a job. Therefore, it seems likely that there is an intergenerational relationship between the employment position of parents and children. Parents without a job are more likely to also have children without a job. This could imply that the process of "catching up" is a slow one.

All in all, ethnicity does not seem to be a very relevant determinant of the labor market position of ethnic minority groups. We emphasize that as far as the labor market position is concerned we analyzed first experiences only. 


\section{References}

[1] Borjas, G.J. (1992) Ethnic capital and intergenerational mobility, Quarterly Journal of Economics, 1992, 107 (1), 123-150.

[2] Borjas, G.J. (1993) The intergenerational mobility of immigrants, Journal of Labor Economics, 11 (1), 113-135.

[3] Borjas, G.J. (1995) Ethnicity, neighborhoods, and human capital externalities, American Economic Review, 85 (3), 365-390.

[4] Card, D., J. DiNardo and E. Estes (1998) The more things change: immigrants and the children of immigrants in the 1940s, the 1970s, and the 1990s, NBER working paper 6519.

[5] Coppel, J., Dumont, J.C. and I. Visco (2001) Trends in immigration and economic consequences, OECD Economics Department Working Paper, no. 284 .

[6] Frick, J.R. en G.G. Wagner (2001) Economic and social perspectives of immigrant children in Germany, IZA Discussion Paper no. 301.

[7] Gang, I.N. (1997) Schooling, parents and country, Quarterly Journal of Economic Research, 66 (1), 180-186.

[8] Gang, I.N., and K.F. Zimmermann (2000) Is child like parent? Educational attainment and ethnic origin, Journal of Human Resources, 35 (3), 550-569.

[9] Graaff, T. de, C. Gorter and P. Nijkamp (2000) Effects of ethnic geographical clustering on educational attainment in the Netherlands, Vrije Universiteit, mimeo.

[10] Kruisbergen, E. and Th. Veld (2002) Een gekleurd beeld, Over beelden, beoordeling en selectie van jonge allochtone werknemers, Assen, Van Gorcum.

[11] Månsson, J. and J. Ekberg (2001) Second-generation immigrants in the Swedish labor market, Discussion paper, Växjö University. 
[12] Oosterbeek, H. (1992) Essays on human capital theory, Dissertation, University of Amsterdam.

[13] Österberg, T. (2000) Economic perspectives on immigrants and intergenerational transmissions, Thesis, University of Goteborg.

[14] Ours, J.C. van, and J. Veenman (2003a) The Netherlands; old emigrants young immigrant country, in: K. Zimmermann (ed.), European migration: what do we know?, Oxford, Oxford University Press, forthcoming.

[15] Ours, J.C. van, and J. Veenman (2003b) The educational attainment of second-generation immigrants in The Netherlands, Journal of Population Economics, forthcoming.

[16] Riphahn, R.T. (2001) Cohort effects in the educational attainment of second-generation immigrants in Germany: an analysis of census data, IZA Discussion Paper no. 291.

[17] Riphahn, R.T. (2001) Dissimilation? The educational attainment of second-generation immigrants, CEPR Discussion Paper, no. 2903.

[18] Skyt Nielsen, H., M. Rosholm, N. Smith and L. Husted (2001) Intergenerational transmissions and the school-to-work transitions of secondgeneration immigrants, IZA Discussion paper no. 296.

[19] Veenman, J. (1995) Onbekend maakt onbemind, Over selectie van allochtonen op de arbeidsmarkt, Assen, Van Gorcum.

[20] Veenman, J. (1996) Heb je niets, dan ben je niets, Tweede-generatie allochtone jongeren in Amsterdam, Assen, Van Gorcum. 
Table 1 Information about schooling and labor market position

$\begin{array}{lccccc}\text { Females } & \text { Turks } & \text { Moroccans } & \text { Surinamese } & \text { Antilleans } & \text { Native Dutch } \\ \text { School - no work } & 42 & 54 & 39 & 30 & 19 \\ \text { School - work } & 12 & 11 & 20 & 24 & 20 \\ \text { No school - no work } & 25 & 17 & 13 & 11 & 12 \\ \text { No school - work } & 21 & 18 & 28 & 35 & 49 \\ & 100 & 100 & 100 & 100 & 100\end{array}$

Working hours ${ }^{a}$ )

- Schoolattenders

$6.4 \quad 5.3$

7.1

6.0

- Schoolleavers

26.1

24.2

24.0

26.0

29.2

Employment rate ${ }^{b}$ )

- Schoolattenders

22

17

34

44

51

- Schoolleavers

46

51

68

76

80

Unemployment rate $^{c}$ )

15

19

13

11

4

Males

School - no work

38

54

40

38

22

School - work

14

16

20

20

24

No school - no work

14

12

13

5

4

No school - work

$34 \quad 18$

27

37

50

$100 \quad 100$

100

100

100

Working hours ${ }^{a}$ )

- Schoolattenders

$\begin{array}{ll}6.3 & 5.7 \\ 31.0 & 28.2\end{array}$

7.4

5.7

6.6

- Schoolleavers

31.0

28.2

27.7

30.1

32.9

Employment rate $^{b}$ )

- Schoolattenders

27

23

33

34

52

- Schoolleavers

71

60

67

88

93

Unemployment rate $^{c)}$

15

26

15

6

4
a) Average per week for those that work
b) Percentage of non-workers in total group
c) Percentage of unemployed in labor force (schoolleavers only) 
Table 2 Probability of having a job conditional on going to school $^{a}$ )

\begin{tabular}{|c|c|c|c|}
\hline & & Females & Males \\
\hline Education & 2 & $-1.09(1.7)$ & $-0.05(0.1)$ \\
\hline \multirow[t]{3}{*}{ (current) } & 3 & $-0.78(1.3)$ & $0.20(0.3)$ \\
\hline & 4 & $-0.77(1.2)$ & $0.11(0.2)$ \\
\hline & unknown & $-0.42(0.7)$ & $0.04(0.1)$ \\
\hline Occupation parents & unknown & $-0.83(6.9)^{*}$ & $-0.56(4.6)^{*}$ \\
\hline \multirow[t]{3}{*}{ Neighborhood } & 1 & $-0.04(0.3)$ & $0.02(0.1)$ \\
\hline & 2 & $-0.25(1.5)$ & $-0.07(0.4)$ \\
\hline & 3 & $0.23(0.9)$ & $-0.22(0.9)$ \\
\hline \multirow[t]{4}{*}{ Ethnic group } & Turk & $-0.40(2.1)^{*}$ & $-0.16(0.8)$ \\
\hline & Moroccan & $-0.51(2.5)^{*}$ & $-0.26(1.3)$ \\
\hline & Surinamese & $-0.17(1.0)$ & $-0.25(1.4)$ \\
\hline & Antillean & $0.06(0.3)$ & $-0.44(1.8)$ \\
\hline \multirow[t]{12}{*}{ Age } & 15 & $-1.81(5.0)^{*}$ & $-2.48(4.6)^{*}$ \\
\hline & 16 & $-1.30(4.0)^{*}$ & $-2.42(4.5)^{*}$ \\
\hline & 17 & $-0.76(2.4)^{*}$ & $-2.11(4.0)^{*}$ \\
\hline & 18 & $-0.58(1.8)$ & $-2.33(4.3)^{*}$ \\
\hline & 19 & $-0.40(1.3)$ & $-2.02(3.7)^{*}$ \\
\hline & 20 & $-0.10(0.3)$ & $-1.94(3.5)^{*}$ \\
\hline & 21 & $-0.34(1.1)$ & $-1.73(3.3)^{*}$ \\
\hline & 22 & $-0.49(1.3)$ & $-1.66(3.0)^{*}$ \\
\hline & 23 & $-0.26(0.7)$ & $-1.56(2.8)^{*}$ \\
\hline & 24 & $-0.31(0.8)$ & $-1.01(1.6)$ \\
\hline & 25 & $-0.17(0.4)$ & $-1.02(1.6)$ \\
\hline & $25+$ & $0.41(0.9)$ & $-1.37(2.3)^{*}$ \\
\hline Constant & & $1.63(2.4)^{*}$ & $1.92(2.3)^{*}$ \\
\hline -loglikelihood & & 320.0 & 322.1 \\
\hline Observations & & 697 & 624 \\
\hline
\end{tabular}


Table 3 Probability to be a schoolleaver, parameter estimates ${ }^{a)}$

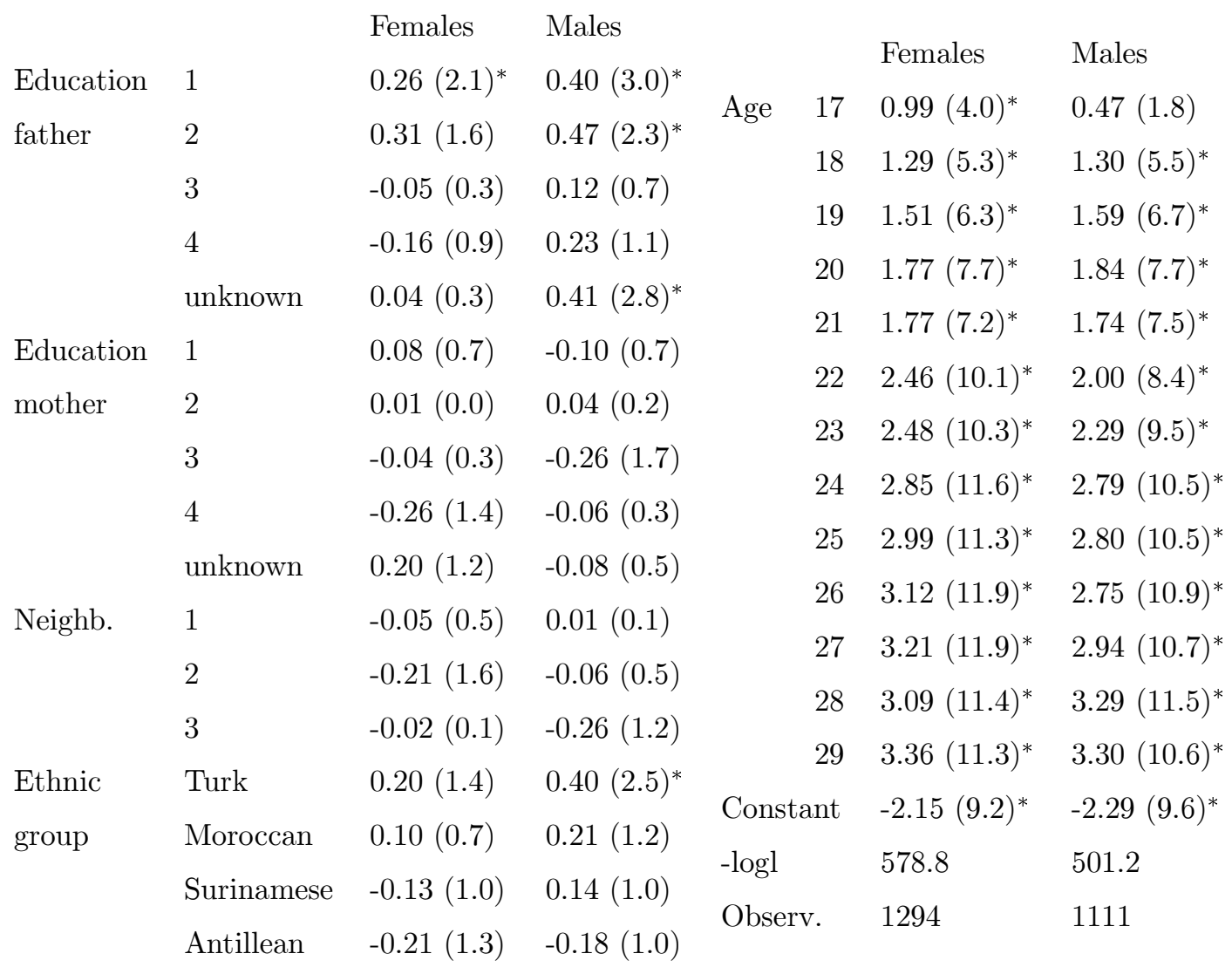

a) t-values in parentheses 
Table 4 Education of schoolleavers ${ }^{a}$ )

Turks Moroccans Surinamese Antilleans Natives

\section{Females}

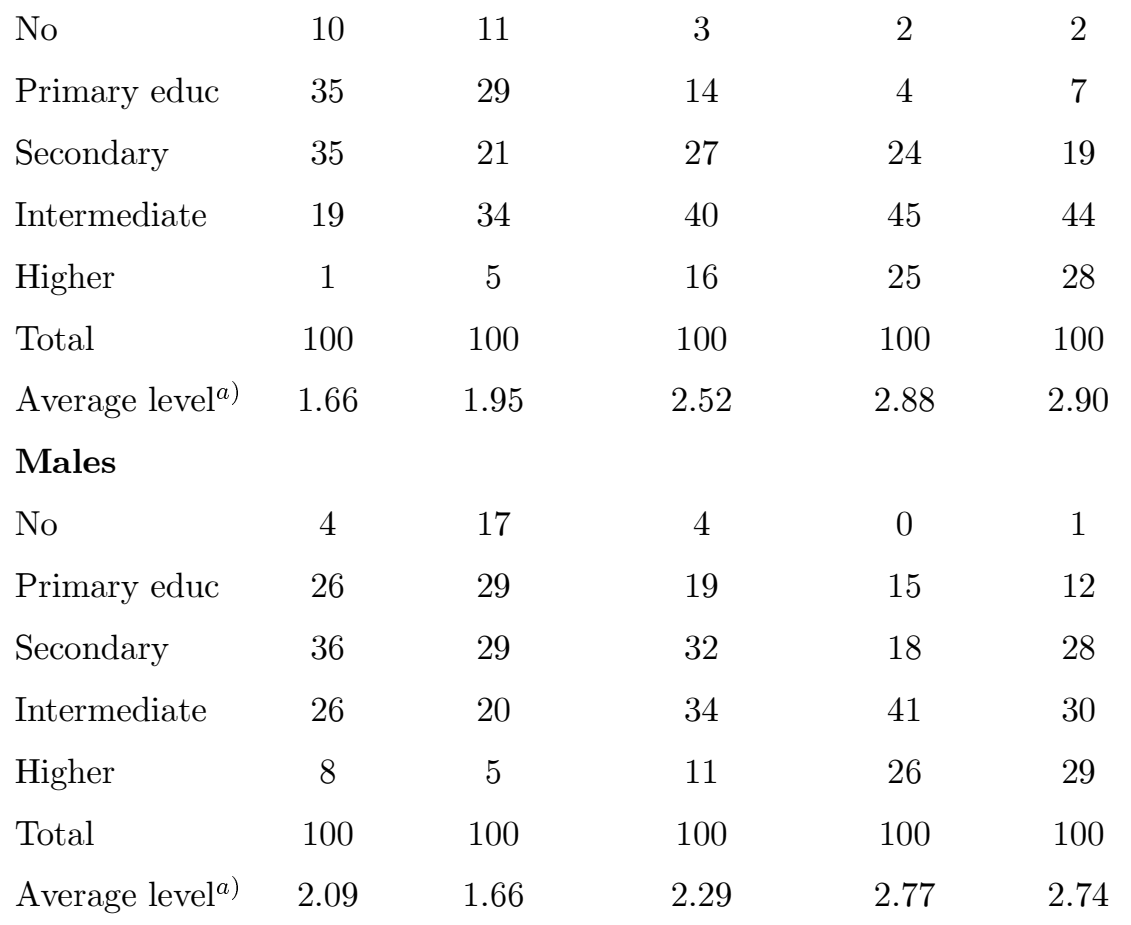

a) Average level based on a scale from 0-4. 
Table 5 Probability to work, conditional on being a schoolleaver ${ }^{a}$ )

\begin{tabular}{|c|c|c|c|c|c|}
\hline \multirow[b]{2}{*}{ Education } & \multirow[b]{2}{*}{1} & \multicolumn{2}{|c|}{ Females } & \multicolumn{2}{|c|}{ Males } \\
\hline & & $0.25(0.9)$ & $0.16(0.5)$ & $-0.05(0.2)$ & $0.10(0.3)$ \\
\hline & 2 & $0.50(1.9)$ & $0.38(1.3)$ & $0.55(1.8)$ & $0.55(1.7)$ \\
\hline & 3 & $0.89(3.4)^{*}$ & $0.78(2.5)^{*}$ & $0.50(1.7)$ & $0.46(1.4)$ \\
\hline & 4 & $0.94(3.1)^{*}$ & $0.80(2.3)^{*}$ & $0.26(0.8)$ & $0.33(0.8)$ \\
\hline \multicolumn{2}{|c|}{ Occupation parents unknown } & - & $-1.05(7.9)^{*}$ & - & $-1.14(6.9)^{*}$ \\
\hline \multirow[t]{3}{*}{ Neighborhood } & 1 & $-0.22(1.7)$ & $-0.21(1.5)$ & $-0.14(0.9)$ & $-0.09(0.5)$ \\
\hline & 2 & $-0.12(0.7)$ & $-0.08(0.4)$ & $-0.37(2.2)^{*}$ & $-0.44(2.3)^{*}$ \\
\hline & 3 & $0.09(0.3)$ & $0.09(0.3)$ & $-0.37(1.3)$ & $-0.30(1.0)$ \\
\hline \multirow[t]{4}{*}{ Ethnic group } & Turk & $-0.62(3.6)^{*}$ & $-0.46(2.5)^{*}$ & $-0.79(3.9)^{*}$ & $-0.53(2.3)^{*}$ \\
\hline & Moroccan & $-0.52(2.7)^{*}$ & $-0.39(1.9)$ & $-0.84(3.3)^{*}$ & $-0.61(2.2)^{*}$ \\
\hline & Surinamese & $-0.22(1.3)$ & $-0.20(1.1)$ & $-0.80(3.7)^{*}$ & $-0.84(3.5)^{*}$ \\
\hline & Antillean & $-0.07(0.3)$ & $-0.06(0.2)$ & $-0.23(0.8)$ & $-0.26(0.6)$ \\
\hline \multicolumn{2}{|c|}{ Potential experience } & $-0.02(0.9)$ & $-0.03(1.7)$ & $-0.00(0.1)$ & $-0.00(0.1)$ \\
\hline \multicolumn{2}{|l|}{ Constant } & $0.37(1.2)$ & $0.77(2.2)^{*}$ & $1.47(4.3)^{*}$ & $1.84(4.9)^{*}$ \\
\hline \multicolumn{2}{|l|}{$\rho$} & $-0.29(1.6)$ & $-0.19(1.0)$ & $-0.66(3.3)^{*}$ & $-0.63(3.1)^{*}$ \\
\hline \multicolumn{2}{|l|}{-loglikelihood } & 919.0 & 883.5 & 720.4 & 685.5 \\
\hline \multicolumn{2}{|l|}{ Observations } & \multicolumn{2}{|c|}{1294} & \multicolumn{2}{|c|}{1111} \\
\hline
\end{tabular}

a) The parameter estimates are based on a bivariate probit model with selection on whether or not an individual has left school. The parameters of the probability to be a schoolleaver are very similar to those presented in Table 3; t-values in parentheses. 
Table 6 Average job characteristics

$$
\text { Turks Moroccans Surinamese Antilleans Natives }
$$

\section{Females}

$\begin{array}{lccccc}\text { \% steady } & 73 & 85 & 74 & 77 & 88 \\ \text { \% full-time } & 67 & 68 & 65 & 64 & 69 \\ \text { average level } & 1.18 & 1.28 & 1.65 & 1.92 & 1.85 \\ \text { net hourly wage } & 12.0 & 12.5 & 14.1 & 14.6 & 14.6\end{array}$

Males

$\begin{array}{lccccc}\text { \% steady } & 81 & 87 & 78 & 85 & 87 \\ \text { \% full-time } & 85 & 95 & 88 & 82 & 93 \\ \text { average level } & 1.29 & 1.40 & 1.42 & 1.73 & 1.89 \\ \text { net hourly wage } & 13.2 & 13.4 & 12.3 & 13.6 & 15.2\end{array}$

a) 1 Dutch guilder $=0.45$ Euro 
Table 7 Parameter estimates job characteristics ${ }^{a)}$

\begin{tabular}{|c|c|c|c|c|c|}
\hline & & & nales & & ales \\
\hline & & Steady job & Full-time job & Steady job & Full-time job \\
\hline Education & 1 & $-0.08(0.2)$ & $-1.11(1.9)$ & $0.26(0.6)$ & $-0.70(1.1)$ \\
\hline & 2 & $0.11(0.2)$ & $-0.84(1.5)$ & $0.64(1.5)$ & $-0.15(0.2)$ \\
\hline & 3 & $0.38(0.8)$ & $-0.74(1.3)$ & $0.88(2.0)^{*}$ & $-0.10(0.1)$ \\
\hline & 4 & $0.59(1.1)$ & $-0.49(0.8)$ & $1.10(2.4)^{*}$ & $0.92(1.0)$ \\
\hline Neighborhood & 1 & $0.25(1.3)$ & $0.16(1.0)$ & $-0.12(0.6)$ & $-0.02(0.1)$ \\
\hline & 2 & $0.37(1.3)$ & $-0.03(0.1)$ & $0.09(0.3)$ & $-0.27(0.9)$ \\
\hline & 3 & $0.29(0.8)$ & $0.40(1.1)$ & $0.07(0.1)$ & $-0.37(0.6)$ \\
\hline Ethnic group & Turk & $-0.59(2.3)^{*}$ & $-0.23(1.0)$ & $0.01(0.0)$ & $-0.15(0.5)$ \\
\hline & Moroccan & $-0.18(0.7)$ & $-0.19(0.8)$ & $0.37(1.0)$ & $0.39(0.8)$ \\
\hline & Surinamese & $-0.54(2.6)^{*}$ & $-0.15(0.8)$ & $-0.26(1.1)$ & $-0.21(0.7)$ \\
\hline & Antillean & $-0.49(1.8)$ & $-0.22(1.0)$ & $-0.02(0.1)$ & $-0.50(1.5)$ \\
\hline Potential exper & ence & $0.06(2.8)^{*}$ & $-0.03(1.5)$ & $0.05(1.8)$ & $0.06(1.8)$ \\
\hline Constant & & $0.28(0.5)$ & $1.17(1.9)$ & $0.12(0.2)$ & $1.20(1.7)$ \\
\hline$\rho$ & & $0.45(1.7)$ & $0.47(1.9)$ & $-0.01(0.0)$ & $0.19(0.5)$ \\
\hline -loglikelihood & & 480.4 & 542.1 & 345.3 & 305.0 \\
\hline Observations & & & 98 & & 187 \\
\hline
\end{tabular}

a) The parameter estimates are based on a bivariate probit model with selection on whether or not an individual has a job. The parameters of the probability to be a schoolleaver are very similar to those presented in Table 5; t-values in parentheses. 
Table 8 Ordered probit function $\operatorname{level}^{a}$ )

\begin{tabular}{|c|c|c|c|}
\hline & & Females & Males \\
\hline Education & 1 & $-0.49(1.6)$ & $-0.60(1.4)$ \\
\hline & 2 & $-0.50(1.6)$ & $-0.38(0.9)$ \\
\hline & 3 & $0.51(1.7)$ & $0.50(1.2)$ \\
\hline & 4 & $1.96(5.9)^{*}$ & $1.99(4.7)^{*}$ \\
\hline Neighborhood & 1 & $0.06(0.4)$ & $0.08(0.6)$ \\
\hline & 2 & $0.11(0.6)$ & $0.26(1.4)$ \\
\hline & 3 & $0.14(0.4)$ & $-0.10(0.2)$ \\
\hline Ethnic group & Turk & $-0.16(0.7)$ & $-0.35(1.9)$ \\
\hline & Moroccan & $-0.30(1.5)$ & $-0.30(1.3)$ \\
\hline & Surinamese & $-0.01(0.1)$ & $-0.37(2.1)^{*}$ \\
\hline & Antillean & $0.13(0.7)$ & $-0.19(0.9)$ \\
\hline Potential expe & ience & $0.04(2.1)^{*}$ & $0.02(0.8)$ \\
\hline Constant & & $1.21(3.6)^{*}$ & $0.98(2.3)^{*}$ \\
\hline$\mu_{1}$ & & $1.64(14.1)^{*}$ & $1.12(12.6)^{*}$ \\
\hline$\mu_{2}$ & & $3.16(18.6)^{*}$ & $2.40(17.0)^{*}$ \\
\hline$\mu_{3}$ & & $4.31(21.0)^{*}$ & $3.78(17.6)^{*}$ \\
\hline$\rho$ & & $-0.08(0.3)$ & $0.28(1.1)$ \\
\hline -loglikelihood & & 712.8 & 610.5 \\
\hline Observations & & 594 & 474 \\
\hline
\end{tabular}

a) The parameter estimates are based on a bivariate ordered probit model with selection on whether or not an individual has a job. The parameters of the probability to be a schoolleaver are very similar to those presented in Table 5; t-values in parentheses. 
Table 9 Wage equations ${ }^{a}$ )

\begin{tabular}{|c|c|c|c|}
\hline & & Females & Males \\
\hline Education & 1 & $-0.17(1.2)$ & $-0.21(1.3)$ \\
\hline & 2 & $-0.12(0.4)$ & $-0.01(0.1)$ \\
\hline & 3 & $0.02(0.1)$ & $0.06(0.4)$ \\
\hline & 4 & $0.17(1.1)$ & $0.32(2.0)^{*}$ \\
\hline Neighborhood & 1 & $0.00(0.1)$ & $0.08(1.7)$ \\
\hline & 2 & $0.01(0.1)$ & $0.08(1.2)$ \\
\hline & 3 & $0.07(0.6)$ & $0.12(1.0)$ \\
\hline Ethnic group & Turk & $0.05(0.6)$ & $0.09(1.7)$ \\
\hline & Moroccan & $0.02(0.3)$ & $0.07(1.0)$ \\
\hline & Surinamese & $0.05(0.8)$ & $-0.04(0.6)$ \\
\hline & Antillean & $0.02(0.2)$ & $-0.05(0.7)$ \\
\hline Full-time & & $0.04(0.7)$ & $-0.01(0.2)$ \\
\hline Steady job & & $0.18(2.9)^{*}$ & $0.15(2.7)^{*}$ \\
\hline Potential exper & ence & $0.032(4.9)^{*}$ & $0.024(3.6)^{*}$ \\
\hline Constant & & $2.35(14.4)^{*}$ & $2.28(13.5)^{*}$ \\
\hline$\lambda$ & & $-0.19(2.0)^{*}$ & $-0.11(1.5)$ \\
\hline $\bar{R}^{2}$ & & 0.21 & 0.28 \\
\hline Observations & & 462 & 352 \\
\hline
\end{tabular}

a) The parameter estimates are based on a OLS regression with a selection term based on whether or not an individual has a job; t-values in parentheses. 


\section{Appendix}

\subsection{Information about the data}

Our data is taken from a nationwide survey (SPVA-1998) among Turks, Moroccans, Surinamese, Antilleans (including Arubans) and native Dutch reference groups in 13 of the largest cities in the Netherlands (Amsterdam, Rotterdam, Den Haag, Utrecht, Eindhoven, Enschede, Almere, Alphen aan den Rijn, Bergen op Zoom, Hoogezand-Sappemeer, Delft, Dordrecht, Tiel). Given the presence of ethnic minorities in the largest cities, the survey may be considered to be representative for the four ethnic minorities. The same does not hold for the native Dutch population, since they are spread more evenly over the whole country. This should not be considered to be a disadvantage, since the native Dutch sample is explicitly used as a reference group for the ethnic minorities in the largest cities. The response rates are comparable with those of other surveys in the largest Dutch cities, although special measures were taken to reach the lower educated ethnic minorities better (matching on ethnicity of interviewers and respondents, translation of questionnaires, et cetera). It seems that although these measures were successful in avoiding the exclusion of the lower educated, they were not successful in diminishing the general non-response rates.

In each household the head of household was asked to answer the general questions on the composition of the household and (if relevant) on its migration history. All members of the household being older than 11 years, were asked to answer the other questions, with the exception of a series of questions on cultural integration and social contacts. These questions were asked alternately in interviews with the head of household and his/her partner and in interviews with the eldest child present during the interview. In this way information was gathered among different numbers of respondents for each set of items.

Second-generation immigrants are defined as individuals who arrived as an immigrant in the Netherlands at an age under 6 years or were born in the Netherlands from at least one parent who came as an immigrant. We restrict ourselves to individuals that were 15 to 29 years at the time of the survey. In 
total we have information about 2405 individuals which are distributed across ethnic group and gender in the following way:

$\begin{array}{lcccccc} & \text { Turks } & \text { Moroccans } & \text { Surinamese } & \text { Antilleans } & \text { Native Dutch } & \text { Total } \\ \text { Males } & 302 & 259 & 320 & 111 & 302 & 1294 \\ \text { Females } & 286 & 215 & 261 & 92 & 257 & 1111 \\ \text { Total } & 588 & 474 & 581 & 203 & 559 & 2405\end{array}$

The variables in our analysis are defined as follows:

- Education, for which we use a series of dummy variables representing primary education (basic education, age group 6-12 years), lower education (lower secondary education - vocational or general, secondary education (intermediate vocational, GCSE and A-levels), higher education (higher vocational and academic education). Less than primary education is the reference group.

- Potential work experience $=$ Age minus age at which the individual left school.

- Education of the father, for which we use a series of dummy variables representing primary education, lower secondary education, intermediate education and higher education. No education is the reference category.

- Education of the mother, specified in the same way as the education of the father.

- Occupation parents = indicator variable for the job level attained by the parents. If the occupation of both parents in known the highest job level is taken. The occupation is scaled from 0 to 4 . If information about the occupation of both parents is missing the parents are assumed to be unemployed.

- Neighborhood = ordinal classification of neighborhoods from 0 to 3 , where $0=\leq 17 \%$ of the population belongs to an ethnic minority group, $1=18$ - 
$34 \%, 2=35-53 \%, 3=\geq 54 \%$ of the population in a neighborhood belongs to an ethnic minority group.

- Steady job = dummy variable in case the worker has tenure, or expects to get tenure. The reference group concerns jobs on fixed term contract, jobs on a temporary basis through in intermediate agency and other temporary jobs.

- Full-time job = job with a normal working week of more than 33 hours. The reference group is a part-time job, i.e. a job with a working week of 32 hours or less.

- Job level = dummy variables based on an ordinal classification ranging from 0 to 3 , where $0=$ elementary, $1=$ lower, $2=$ intermediate, $3=$ higher. Job level 0 is the reference category.

Table A1 gives information about the age distribution of the 5 groups of individuals we distinguish in the analysis. Clearly, despite the fact that the age band is limited there are still important differences in the age distribution across the groups. Whereas, on one side almost $60 \%$ of the Moroccans in the age from 15 to 29 is below 20 , on the other side this holds for less than $25 \%$ of the native Dutch individuals in our sample. The average age of the Moroccan females in our sample is 19.3 years, whereas the average age of the Dutch in our sample is 23.1 years. While of the native Dutch youngsters almost half is in the age brackets from 25 to 29 years, less than $10 \%$ of the Moroccan youngsters is in this age interval. These differences in age distribution will of course influence to what extent individuals from a particular group have finished their education and have entered the labor market. 
Table A1 Age distribution by gender and ethnic group

Turks Moroccans Surinamese Antilleans Native Dutch

\section{Females}

Age

$\begin{array}{lccccc}15-19 & 46 & 59 & 40 & 29 & 20 \\ 20-24 & 35 & 31 & 33 & 38 & 33 \\ 25-29 & 19 & 10 & 27 & 33 & 47 \\ \text { Total } & 100 & 100 & 100 & 100 & 100 \\ \text { Av. age } & 20.3 & 19.3 & 20.8 & 22.0 & 23.1\end{array}$

Males

Age

$\begin{array}{lccccc}15-19 & 45 & 59 & 47 & 34 & 24 \\ 20-24 & 36 & 34 & 30 & 26 & 28 \\ 25-29 & 19 & 7 & 23 & 40 & 48 \\ \text { Total } & 100 & 100 & 100 & 100 & 100 \\ \text { Av. age } & 20.6 & 19.2 & 20.6 & 22.2 & 23.2\end{array}$

Table A2 shows the distribution of ethnic groups across neighborhoods. Ethnic minorities have a higher probability than native Dutch to live in a neighborhood with a high share of ethnic minorities. Yet, the segregation at the level of the neighborhoods is rather limited. Whereas about $75 \%$ of all native Dutch youngsters live in a neighborhood with less than $17 \%$ ethnic minorities, also about $60 \%$ of the Antilleans live in such neighborhoods, about $45 \%$ of the Surinamese youngsters, about $40 \%$ of the Turkish youngsters and about $35 \%$ of the Moroccan youngsters. In the neighborhoods with the highest share of ethnic minorities (more than 54\%), there are no native Dutch, but also the percentages of ethnic minorities living in such areas are small, about $10 \%$ for Turks and Moroccans and only about 3\% for Surinamese and Antilleans. 
Table A2 Distribution across neighborhoods by gender and ethnic group (\%)

Females Turks Moroccans Surinamese Antilleans Native Dutch

Ethnic conc.

$\begin{array}{lccccc}\leq 17 \% & 40 & 34 & 44 & 59 & 77 \\ 18-34 \% & 26 & 34 & 34 & 24 & 19 \\ 35-53 \% & 22 & 24 & 19 & 14 & 4 \\ \geq 54 \% & 12 & 8 & 3 & 3 & 0 \\ \text { Total } & 100 & 100 & 100 & 100 & 100\end{array}$

\section{Males}

Ethnic conc.

$\begin{array}{lccccc}\leq 17 \% & 39 & 34 & 46 & 62 & 73 \\ 18-34 \% & 26 & 31 & 29 & 32 & 22 \\ 35-53 \% & 23 & 25 & 22 & 5 & 5 \\ \geq 54 \% & 12 & 10 & 3 & 1 & 0 \\ \text { Total } & 100 & 100 & 100 & 100 & 100\end{array}$

Table A3 shows the distribution of occupational level of parents across ethnic groups indicating that especially Turkish and Moroccan youngsters have a high probability to have a parent with an unknown occupation. Also among native Dutch youngsters this probability is high, which indicates that only part of the missing information can be related to unemployment of the parents. 
Table A3 Distribution of occupational level parents by gender and ethnic group (\%)

Females Turks Moroccans Surinamese Antilleans Native Dutch Occ. level

$\begin{array}{lccccc}0 & 10 & 9 & 7 & 7 & 9 \\ 1 & 27 & 18 & 25 & 24 & 26 \\ 2 & 10 & 8 & 21 & 21 & 24 \\ 3 & 1 & 2 & 8 & 8 & 10 \\ 4 & 0 & 0 & 3 & 8 & 7 \\ \text { unknown } & 52 & 63 & 36 & 32 & 24 \\ \text { Total } & 100 & 100 & 100 & 100 & 100 \\ \text { Males } & & & & & \end{array}$

Occ. level

$\begin{array}{lccccc}0 & 12 & 11 & 10 & 10 & 7 \\ 1 & 16 & 13 & 28 & 21 & 25 \\ 2 & 10 & 8 & 22 & 23 & 21 \\ 3 & 2 & 3 & 9 & 13 & 27 \\ 4 & 9 & 0 & 2 & 1 & 7 \\ \text { unknown } & 60 & 65 & 29 & 32 & 23 \\ \text { Total } & 100 & 100 & 100 & 100 & 100\end{array}$




\subsection{Labor force and unemployment}

In Table 5 we present parameter estimates of the probability to have a job conditional on being out of school. Here, we present some alternative analyses of the labor market position of second-generation immigrants.

Table A4 Probability to be part of the labor force, conditional on being a schoolleaver ${ }^{a}$

$\begin{array}{llcc} & & \text { Females } & \text { Males } \\ \text { Education } & 1 & 0.43(1.5) & 0.40(1.2) \\ & 2 & 0.60(2.2)^{*} & 0.81(2.3)^{*} \\ & 3 & 1.01(3.6)^{*} & 0.48(1.4) \\ & 4 & 1.23(3.5)^{*} & 0.65(1.4) \\ \text { Occupation parents unknown } & -0.73(5.4)^{*} & -0.69(3.7)^{*} \\ \text { Neighborhood } & 1 & -0.21(1.4) & -0.35(1.7) \\ & 2 & -0.05(0.3) & -0.22(1.0) \\ & 3 & -0.03(0.1) & -0.34(1.0) \\ \text { Ethnic group } & \text { Turk } & -0.45(2.2)^{*} & -0.53(1.6) \\ & \text { Moroccan } & -0.25(1.1) & -0.35(0.9) \\ & \text { Surinamese } & 0.01(0.0) & -0.60(1.9) \\ \text { Potential experience } & \text { Antillean } & 0.26(0.9) & -0.09(0.2) \\ \text { Constant } & & -0.09(4.4)^{*} & -0.03(1.2) \\ \rho & & 0.90(2.8)^{*} & 2.05(4.4)^{*} \\ & & -0.24(1.3) & -0.77(3.0)^{*} \\ \text {-loglikelihood } & & & \\ \text { Observations } & & 854.3 & 630.3 \\ & & 1294 & 1111\end{array}$

a) The parameter estimates are based on a bivariate probit model with selection on whether or not an individual has left school. The parameters of the probability to be a schoolleaver are very similar to those presented in Table 3; t-values in parentheses. 
In Table A4 the dependent variable is the probability to be part of the labor force. For females the parameter estimates in Table A4 are very much the same as in Table 5. For males now none of the coefficients of the ethnicity groups is significantly different from zero. Nevertheless, the parameter estimates are not very different from those in Table 5.

Table A5 Probability to be unemployed, conditional on being in the labor force ${ }^{a)}$

Females Males

a) The parameter estimates are based on a bivariate probit model with selection on whether or not an individual is in the labor force; $t$-values in parentheses.

Table A5 shows parameter estimates for the probability of being unemployed conditional on being part of the labor force. Since the number of unemployed 
is rather small we merged Turkish and Moroccans into "Mediterranean" and Surinamese and Antilleans into "Carribeans". As shown the dummy variable indicating whether of not the parents are unemployed has a significant effect on the unemployment probability. And among Carribeans the unemployment rate is higher as among other groups. 


\section{IZA Discussion Papers}

\begin{tabular}{|c|c|c|c|c|}
\hline No. & Author(s) & Title & Area & Date \\
\hline 633 & A. D. Kugler & Employee Referrals and Efficiency Wages & 5 & $11 / 02$ \\
\hline 634 & $\begin{array}{l}\text { A. D. Kugler } \\
\text { R. M. Sauer }\end{array}$ & $\begin{array}{l}\text { Doctors Without Borders: The Returns to an } \\
\text { Occupational License for Soviet Immigrant } \\
\text { Physicians in Israel }\end{array}$ & 1 & $11 / 02$ \\
\hline 635 & $\begin{array}{l}\text { M. Karanassou } \\
\text { D. J. Snower }\end{array}$ & An Anatomy of the Phillips Curve & 3 & $11 / 02$ \\
\hline 636 & $\begin{array}{l}\text { M. Karanassou } \\
\text { H. Sala } \\
\text { D. J. Snower }\end{array}$ & $\begin{array}{l}\text { A Reappraisal of the Inflation-Unemployment } \\
\text { Tradeoff }\end{array}$ & 3 & $11 / 02$ \\
\hline 637 & $\begin{array}{l}\text { H. Bonin } \\
\text { W. Kempe } \\
\text { H. Schneider }\end{array}$ & $\begin{array}{l}\text { Household Labor Supply Effects of Low-Wage } \\
\text { Subsidies in Germany }\end{array}$ & 3 & $11 / 02$ \\
\hline 638 & $\begin{array}{l}\text { L. McLeod } \\
\text { M. R. Veall }\end{array}$ & $\begin{array}{l}\text { The Dynamics of Food Deprivation and Overall } \\
\text { Health: Evidence from the Canadian National } \\
\text { Population Health Survey }\end{array}$ & 2 & $11 / 02$ \\
\hline 639 & G. Saint-Paul & Are Intellectual Property Rights Unfair? & 3 & $11 / 02$ \\
\hline 640 & $\begin{array}{l}\text { J. Hartog } \\
\text { N. Jonker } \\
\text { H. van Ophem }\end{array}$ & $\begin{array}{l}\text { Dual Track or Academic Route for Auditors: } \\
\text { Does It Matter? }\end{array}$ & 6 & $11 / 02$ \\
\hline 641 & $\begin{array}{l}\text { J. Hartog } \\
\text { L. Diaz Serrano }\end{array}$ & $\begin{array}{l}\text { Earning Risk and Demand for Higher Education: } \\
\text { A Cross-Section Test for Spain }\end{array}$ & 2 & $11 / 02$ \\
\hline 642 & $\begin{array}{l}\text { J. Hartog } \\
\text { A. Zorlu }\end{array}$ & $\begin{array}{l}\text { The Effect of Immigration on Wages in Three } \\
\text { European Countries }\end{array}$ & 1 & $11 / 02$ \\
\hline 643 & $\begin{array}{l}\text { A. Björklund } \\
\text { M. Sundström }\end{array}$ & $\begin{array}{l}\text { Parental Separation and Children's Educational } \\
\text { Attainment: A Siblings Approach }\end{array}$ & 6 & $11 / 02$ \\
\hline 644 & $\begin{array}{l}\text { J. D. Brown } \\
\text { J. S. Earle }\end{array}$ & $\begin{array}{l}\text { Job Reallocation and Productivity Growth Under } \\
\text { Alternative Economic Systems and Policies: } \\
\text { Evidence from the Soviet Transition }\end{array}$ & 4 & $11 / 02$ \\
\hline 645 & $\begin{array}{l}\text { M. Karanassou } \\
\text { H. Sala } \\
\text { D. J. Snower }\end{array}$ & $\begin{array}{l}\text { Long-Run Inflation-Unemployment Dynamics: } \\
\text { The Spanish Phillips Curve and Economic Policy }\end{array}$ & 3 & $11 / 02$ \\
\hline 646 & $\begin{array}{l}\text { L. Graham } \\
\text { D. Snower }\end{array}$ & The Return of the Long-Run Phillips Curve & 3 & $11 / 02$ \\
\hline 647 & $\begin{array}{l}\text { C. Grund } \\
\text { D. Sliwka }\end{array}$ & Envy and Compassion in Tournaments & 1 & $11 / 02$ \\
\hline 648 & $\begin{array}{l}\text { C. Schnabel } \\
\text { T. Schank } \\
\text { J. Wagner }\end{array}$ & $\begin{array}{l}\text { Works Councils - Sand or Grease in the } \\
\text { Operation of German Firms? }\end{array}$ & 3 & $11 / 02$ \\
\hline 649 & $\begin{array}{l}\text { J. van Ours } \\
\text { J. Veenman }\end{array}$ & $\begin{array}{l}\text { From Parent to Child: Early Labor Market } \\
\text { Experiences of Second-Generation Immigrants } \\
\text { in the Netherlands }\end{array}$ & 1 & $11 / 02$ \\
\hline
\end{tabular}

An updated list of IZA Discussion Papers is available on the center's homepage www.iza.org. 